\title{
Study on the Fiscal and Taxation Policies of Land Fallow in China
}

\author{
Lingling Qin ${ }^{1, a}$ and Jinyao $\mathrm{Li}^{2, \mathrm{~b}}$ \\ ${ }^{1}$ School of Investment and Insurance,Harbin Finance University,No.65,Diantan Road,Xiangfang \\ District,Harbin City, Heilongjiang Province, China \\ ${ }^{2}$ School of Public Finance and Administration,Harbin University of Commerce,No.1,Xuehai \\ Street,Songbei District,Harbin City, Heilongjiang Province, China \\ a373675370@qq.com, binyao421@163.com
}

\begin{abstract}
Keywords: Land fallow; Ecological environment; Clearly-established ownership; Financial subsidies
\end{abstract}

\begin{abstract}
Cultivated land is the most valuable agricultural resource. Facing the "red light" of environmental resources, such as the irrational agricultural resources, the food supply pressure of the over-population and the super-intensive utilization of water, taking advantage of the abundant timing of domestic phased food supply, fallow system has its inevitability in China. Beginning with land retirement in Xia, Shang and Zhou dynasties, and introducing the historical evolution of land fallow in China, we think it is imminent and significant to establish land fallow system in China. Drawing lessons from the conservation reserve program in the United States and the European Union, the author thinks that our country should formulate corresponding fiscal and tax laws and regulations, implement differential and purposeful financial subsidies, establish a special fund for land fallow, and gradually perfect our country's land fallow system.
\end{abstract}

\section{Introduction}

Cultivated land is the most valuable resource and the lifeblood of food production. China's natural shortage of agricultural resources and excessive population pressure on food supply make the super-use of cultivated land and water resources, so resources and environment have been lit "red light." At the Fifth Plenary Session of the 18th CPC Central Committee, it is proposed that the implementation of crop rotation and fallow system is not only beneficial to the recuperation and sustainable development of arable land, but also helps to balance the contradiction between supply and demand of grain, stabilize the income of peasants and reduce financial pressure at the stage of abundant food supply opportunities at home and abroad. Both the 2016 Government Work Report and the Document No.1 of the Central Government have clearly set forth the requirements for the pilot project of exploring the implementation of the fallow system of crop rotation. However, the theoretical basis and practical experience of arable land fallow in China are still very weak, so we need to do theoretical and empirical research on the fallow system of land rotation. On the basis of this, we begin to study the land fallow system on the basis of the above situation.

\section{The Historical Evolution of the System of Land Fallow in China}

Fallow is to give up farming and recuperation after harvest. Throughout the development of history, the fallow system mainly has two forms: fallow and variation of fallow.

Fallow was an ancient farming method which was adopted by our country during the Xia,Shang and Zhou dynasties and was called "Deserted fallow". The agricultural production technology of Zhou dynasty is characterized by the prevalence of fallow and coupling farming. The fallow system is what the document refers to $\mathrm{Zi}$, Xin, She. Since the Warring States Time, the main grain-producing areas in the northern of China have gradually abandoned the forms of raising land for fallow cultiva

-tion and replaced them with intensive cultivation of crop rotation and fertilization and rearing. However, different forms of fallowing system still exist in different historical periods. For example, during the Han Dynasty rice paddy area in the southern part of the Yangtze River, the "Fire farming 
water weeding" was practiced in the form of fallow and mainly relied on the irrigation of the plowed fields. This type of fallow was used by the Song and Yuan Dynasties and was replaced by winter fallow. The period of winter fallow is one to two years. The subsequent winter fallow began to implement the method of deep plowing and soaking with the main field, which is conducive to improving the soil structure, easy to restore fertility, rice yield also increased. In addition, winter paddy fields as the main mode of fallowing are also endemic in Sichuan Province.

In the long history of China, there are still some disguised fallow systems, such as the Daitianfa and the Quzhongfa in the Han Dynasty, the pro-Tian law in the Ming Dynasty and so on. The so-called on behalf of Daitianfa refers to "sowing in Langzhong, seedlings above the leaves, a little ridge grass, because of its soil with its seedling root "; the method of Quzhong is to divide the land into different regions, and the selective intensive cultivation is practiced in the area to achieve high yield of grain; The pro-tian law is also through concentrated intensive cultivation of a certain area of land to achieve high yield, and the rest of the land is normal tillage, after year rotation.

Throughout the ancient land fallow in China, we found that there are several characteristics: First, the main way to use land fallow in winter; Second, when the relationship between man and land is relaxation, fallow is prevalent; Third, when the food unit area is stable, the development of fallow is faster.

\section{The Significance of Establishing Land Fallow System}

The establishment of land fallow system has a very important role for "keeping food in the fields", enhancing the stamina of agricultural development, promoting the balance of grain supply and demand, ensuring food security, reducing the state's financial and bank burden, and improving the level of farmers' scientific farming.

Conducive to the Basic Balance between Grain Supply and Demand. Since the founding of the People's Republic of China, the party and the government have attached great importance to grain production and adopted a series of policies to protect and encourage the peasants in the production of grain. The grain has been growing for more than 10 consecutive years. Under the premise of resolving the national grain supply, there are surplus food supplies, especially the main grain products District warehouse full, inventory backlog, serious aging grain. Establishing the system of land fallow system to reduce food supply by controlling the planting area of grain can alleviate the current situation of relative surplus of foodstuffs. In the meantime, if there is a shortage of food supplies, the grain area can be restored and the basic balance between grain supply and demand can be restored to ensure national food security.

Conducive to the Sustainable Development of Agriculture. China is not only a big agricultural country, but also a large population country. The relationship between man and land is very tense. Although there has been a phased surplus in food production, the food supply remains tense in the long run.In the present situation, relatively excessive supply of agricultural products, agricultural prices continued to decline, is not conducive to increasing farmers. For a long time, under the pressure of agricultural products supply, the land force of cultivated land has been overused. The groundwater has been overexploited. The chemical fertilizers and pesticides have been widely used. The agricultural resources environment has been overwhelmed. The fallow rotation of cultivated land will reduce the intensity of development and utilization, reduce the investment of chemical fertilizers and pesticides, facilitate the restoration of agricultural surface pollution, relieve the pressure of ecological environment, and promote sustainable agricultural development.

Help to Reduce the Burden on Financial Banks. In China, we have to subsidize the stocks of grain each year, subsidizing the grain prices, which are so huge that the state finances are overwhelmed. In particular, China has a long inventory of grain and the quality of its products is seriously deteriorated. The large amount of potential losses has brought huge credit risks to the banks. The establishment of the land fallow system, the adjustment of grain acreage, the promotion of grain stocks at a reasonable rate, and the continuous improvement of the quality of grain are conducive to reducing the state financial subsidies for food stocks. 
Conducive to Improving the Competitiveness of Agricultural Quality and Efficiency. After decades of development, the problem of China's agriculture being large rather than strong, multiple but not superior, and weak competitiveness has become increasingly prominent. It is imperative to promote the structural reform of the agricultural supply side and promote the transformation and upgrading of agriculture. By establishing fallow system, adjusting and optimizing planting structure, reducing the supply of surplus agricultural products and increasing the supply of scarce agricultural products, the state can not only balance the prices of agricultural products, but also meet the needs of diversified consumption and improve the quality and efficiency of agricultural supply.

Beneficial to Improve the Cultural Level of Farmers' Science and Education. After the implementation of the fallow land, because the peasants planted less area, the peasants idle time increased. On the one hand, it reduces the labor intensity of peasants 'production and restores the peasants the opportunity to recuperate. At the same time, it further enriches the amateur cultural life of peasants so that peasants' ideology, culture and physical quality are continuously improved. On the other hand, the township governments and village committees may also organize agricultural technology training for farmers in scientific farming during the slack season, in order to raise their scientific and technological and cultural level. Especially the scientific farming level will promote farmers' investment in science and technology, adjust grain planting structure, and implement agricultural optimization and upgrading.

\section{Analysis of Fiscal and Taxation Policies of Land Fallow System in Developed Countries}

Conservation Reserve Program in USA. After the independence of the United States, because of the rapid population growth, the land was spared no effort and the planting area of crops continued to expand. However, the "black storm" in the United States broke out due to intensive farming without taking adequate soil and water conservation measures into account. In response to this dilemma, the U.S. Congress authorized the USDA to conduct a study on soil erosion in 1929 and set up a special fund. Subsequently, the United States formulated a series of special laws and regulations as the legislative basis for the implementation and regulation of the policy, such as the Agricultural Adjustment Act of 1933, the Soil Conservation and Domestic Quotas Act of 1936, the Food and Agriculture Act of 1965, the Food Safety Bill of 1985 and so on. Since1986, a nationwide agro-environmental project called Conservation Reserve Program(CRP) has been implemented. The main objectives of the Plan are to subsidize those soil-erosive and other environmentally sensitive crop sites, to support crop producers crop producers implement long-term vegetation protection measures such as returning farmland to forest and grassland, and eventually to achieve the goal of improving water quality, controlling soil erosion and improving the habitat of wildlife and habitats. The United States Agriculture Bill again authorizes the implementation of CRP in 2014 and also makes some policy adjustments. The main contents includes: It's proposed to reduce the total amount of registration from the current 32 million acres to 24 million acres by FY 2018; in some special cases, it's proposed to relax the restrictions on land for grazing Cultivated Land (CRP); it's proposed to abolish the GRP and the corresponding grasslands contract goes into effect under the CRP; under certain conditions, CRP participants are given more opportunities to terminate the contract early.

Land Fallow Plan in EU. Before the 1980s, the EU's price support led to a large surplus of agricultural products and a drop in peasants' incomes.In1988, the EU launched a five-year voluntary fallow program to control and reduce food production and budget expenditures. In the early 1990s, the major exporters of agricultural products led by the United States strongly criticized the EU's export subsidies for agricultural products. In 1992, when the EU launched the "Macs Harry Reform", land retirement became a compulsory measure for the EU to reduce grain output. In 1999, the EU's" 2000 Agenda" proposed to build a model of agricultural development in Europe and carry out more thorough reforms of agricultural policies: the price subsidies for agricultural products have been drastically reduced, and government continued to carry out compulsory fallow, and subsidies for fallowing were funded by the governments of member countries. In 2008, the EU adjusted the rate of fallow to zero in response to the international rise in food prices. The mandatory fallow 
system has been abolished since 2009 and voluntary fallow plans have been adopted.

Land Fallow in Japan. In response to the over-production of rice in the 1960s, the Japanese government implemented a fallow-farming project in 1970 to reduce the production of rice by controlling the planting area. The government combined with price subsidies and import tariffs and other policy measures to protect the high level of domestic rice prices to protect the income of farmers. In 1993, the Uruguay Round "Agreement on Agriculture" added an environmental goal of fallowing to improve the ecological environment and the protection of species diversity. The staple food act of 1995, for the first time, wrote fallow law and allowed farmers to decide on their own whether to participate in the fallow program. However, during the implementation process, the Ministry of Agriculture, Forestry and Fisheries (MAFF) and the Japan Agricultural Cooperative (JA) demanded that all farmers participate in the fallow program and assign the task of transferring rice fields to villages instead of individual farmers. In order to meet the requirements of the WTO agreement on agriculture, the agricultural subsidy policy was adjusted in 2007 by encouraging the large-scale operation of agriculture to increase the market competitiveness of rice and thus reduce the government's subsidy expenditure.

\section{Suggestions on Perfecting the Fiscal and Tax Policies of Land Fallow in China}

Formulate the Corresponding Tax Laws and Regulations. Before the western developed countries implemented the land fallow plan, basically the system was not implemented and the law came first. For example, the United States formulated a series of special laws and regulations as the land fallow system to implement and regulate the legislative basis, such as Agricultural Adjustment Act of 1933, Soil Conservation and Quota Law of 1936, Food and Agriculture Act of 1965, and so on. The formulation and implementation of these laws and regulations make the land fallow system in western countries achieve the purpose of smooth implementation. Therefore, prior to implementing the land fallow plan in China, we should also formulate specific laws and regulations to make the implementation of the land fallow a legal basis.

Implement Differential and Purposeful Financial Subsidies. The western developed countries implement the land fallow system at the expense of land owners or users, so there is a widespread phenomenon of subsidizing the owners or users of fallow land. For example, the United States adopted a tax on specific crops to compensate landowners who have limited agricultural production so as to reduce their cultivated land and control the supply of agricultural products. The EU adopted a policy of subsidizing the export of agricultural products. Therefore, the land fallow system is adopted to subsidize the fallow land, and I think we should note the following: First, the implementation of the subsidy policy should be linked to the purpose of land fallow. Through subsidies, the United States encouraged farmers to reorganize "land-enhanced" crops with "plant-worthy" crops to effectively combine soil protection and control over production policies. Second,subsidies should be given priority to direct subsidies, supplemented by price subsidies. In the process of implementing land fallacies, western countries started to adopt a price subsidy approach and gradually changed them to direct subsidies in recent years.

Establish a Special Fund for Land Fallow System. Western countries in the implementation of land fallow system generally established a special fund, one for the study of soil erosion, the other for the implementation of the compensation of land fallow. In the process of implementing the land fallow system in China, in order to ensure the long-term implementation of the land fallow system, we should also establish a special land fallow fund. The initial fund can be set up by financial appropriation, and the latter should guarantee a sustainable source of funds. For example, special taxes can be collected or funded by various provinces to ensure the long-term funding of the later period.

Implement Fallow Plans According to Local Conditions. In the implementation of the land fallow plan, western countries have formulated different plans for fallowing according to their respective purposes. For example, for the purpose of ecological protection and alleviating the pressure caused by overproduction of agricultural products, the United States adopted the fallow types of planning fallow, returning farmland to forest and permanently converting farmland to 
forests. In order to protect peasants' income and maintain the high price of rice to cope with the pressure of world trade, Japan adopted a mode of permanent fallow, rotation fallow and management of fallow. In the vast territory of our country, the degree of damage, sensitivity, resource endowment and grain production tasks vary among different provinces and regions. Therefore, we should adopt different specific policies in the formulation of the land fallow plan to avoid implementing a one-size-fits-all approach.

Implementation of differential compensation standards. For example, in the process of implementing the CRP plan in the United States, farmers will put forward their lowest acceptable price based on the opportunity cost of land and the corresponding cost of planned implementation. In addition, each state has the right to allocate funds and has some flexibility so as to ensure that funds are used for the projects that are most in need of protection. From this perspective, the subsidy standard can be specific to each family who has different standards. China's ecological compensation should give due consideration to the different situations in different places, properly refine the economic compensation standards, and implement the policy of zoning control so as to make it more in line with the local conditions and so as to ensure the environmental efficiency of capital utilization.

\section{Acknowledgements}

Heilongjiang Philosophy and Social Sciences Planning Project: Research on the Financial Support for the Industrial Transformation and Upgrading of Longjiang in the New Situation(Project No. 16JYA01)

\section{References}

[1] J. Johnson and B. Maxwell: Journal of Rural Studies ,Vol. 17 (2001) No.3, P.323.

[2] J. L. Jiang, Q. Y. Yang and J. Z. Yang: Journal of Southwest University(Natural Science Edition), (2017) No.1, P.165. (In Chinese)

[3] V. B. Josh and W. Yvonne: Conservation Biology, Vol. 18 (2004) No.4, P.987.

[4] G. Q. Cheng and X. S. Ceng: Sub National Fiscal Research, (2016) No.7, P.87. (In Chinese)

[5] Information on http://www.tyfanbu.com/jingji/20170112/14169504.html.

[6] Information on http://www.gov.cn/xinwen/2016-07/01/content_5087269.htm.

[7] C. C. Cheng, Z. X. Lu and B. Z. P: Acta Agriculturae Universities Jiangxiensis, (2004) No.3, P.439.(In Chinese)

[8] M. Stubb and K. Yang: World Agriculture, (2017) No.2, P.162. (In Chinese)

[9] B. Darcy and B. Graro: Agriculture, Ecosystems and Environment, Vol. 107 (2005) No.2, P.231.

[10] S. Rosemaric, B. Gert, L. Jana and P. Holger: Journal for Nature Conservation, Vol. 18 (2010) No.4, P.327. 